\title{
Analysis of Reasons for Chinese Civil Servants Resigning from Office
}

\author{
Li Yongkang \\ School of Public Management, Yunnan University of Financeand Economics, Kunming, P.R.China 650221 \\ (E-mail:121651831@qq.com)
}

\begin{abstract}
This paper adopts the methods of literature and case study to analyse the reasons deeply for Chinese CSRO according to the data since 1978. The analysis result shows that there are 4 perspectives including 11 reasons to impact on CSRO. Perspective 1, the environment of political and economic, including the pull factors of the policies of economic construction and reform and opening up, the push factors of institutional reform and cut redundant personnel, and the establishment of diversified values. Perspective 2, institutional reasons for CSRO, including the resignation system supplies the legitimacy to resign, and the social security system related to resign has been perfected. Perspective 3, incentive system failure, including the lower salary, the "ceiling" of promotion and unfair treatment. Perspective 4, individual reasons, including willing to try challenging work or do what one likes, job burnout and the change of family relationships.
\end{abstract}

Keywords:Civil Servants Resigning from Office(CSRO), Reason, China

\section{Introduction}

China civil servants refers to all public staff who perform official duties according to law, and gain national administrative identification, whose salary and benefits burden with national finance (NPC,2005). Civil Servants Resigning from Office(CSRO) is a right of civil servants, refers to the action or process that a civil service voluntary applies according to the law, after approved by the appointment and removal organ, stops one's job and gives up the civil servant status. It is one form of Civil Servants Resignation, another is Civil Servants Resigned Leadership(CSRL).

Since October 1993, the State Council in China has promulgated "Provisional Regulations on State Civil Servants", there is a clear basis for CSRO management. According to the statistics,"from1996 to the end of 2003, the total number of CSRO is 32549."(Yearbook of people's Republic of China, 2004) From 1998 to 2002, the proportion of CSRO in China is $0.5 \%$, $0.6 \%$ o, $0.8 \%$ o, $1.1 \%$ o, $1.1 \%$, resigned number ratio increased year by year, the 2002 CSRO number is 5585.(Pan Chenguang,2005).

Since 2006 the implementation of civil servant law, some new changes have been taking place for CSRO, civil servants who own stronger professional become the object of enterprise to dug talent. The anti tax avoidance expert of tax system has resigned to be tax venture partner of international accounting firm(Wang Chao,2012). The CSRC officials resign to join stock company. According to the statistics of fund company open recruitment instructions, there have been nearly 50 
securities civil servants to resign to be the fund company executive(2012). "2013 work report of Supreme People's Court" mentioned that, in the past 5 years, some judges of local courts loss seriously(Wang Shengjun,2013). From 2008 to 2013 of five years, there are more than 500 judges resigned and mobilized to leave in Beijing court system(Li Tianji,2014). According to an official of politics department of Supreme People's court in charge estimation, $5 \%$ judge will leave the team of judges before their retirement age in China(Shen Nianzu,2014).

What are the reasons for CSRO? Based on the data of CSRO since reform and opening up, this article adopts the method of literature and case study to deep analysis of the reasons for contemporary CSRO in China.

Due to lack of thinking or underestimates of the vital interests of the broad masses, major projects often become the fuse of group events in China. Major projects' social stability risk is a branch of social stability risk, specifically referring to social unrest, disorder, and other phenomena induced by major project-related elements. Social stability risk assessment on major projects is an important part of projects' social impact assessment system and an important institutional measure to guard against social risks.

\section{Literature Review}

Through combing the literature, the author finds that domestic and foreign scholars had studied the reasons of CSRO from different angles.

Huang Renzong (2001) summarized the reasons of CSRO to be the fundamental factor and specific reason from the perspective of senior officials. Song Bin, Bao Jing and Xie Xin(2005) summed up the reasons of CSRO as "eight no": creativity cannot be played; self realization is not met; treatment not to enjoy; not get the promotion opportunities; lack of attention to interpersonal relations; not harmonious; work and life difficult unresolved;cannot display. Wu Bo(2005)had a survey about the flow of China talent to do, a total of 1652 copies of valid questionnaires and 8 types of occupations, including 112 civil servants. The result shows that when civil servants turnover, the first four factors to be considered are salary, career development, the ability to play, work environment; The last four factors are: promotion opportunity, appropriate post, personnel mechanism, prospect of organization. Li Xiaoyu, Gao Dongdong and Gao Feng(2007) conducted a questionnaire survey on job burnout and turnover intention of Party and government cadres, the results shows that there is a significant positive correlation between job burnout and turnover intention, and job burnout can directly or indirectly affect turnover intention. Liu 
Junsheng(2009) concluded the reasons of CSRO: Be not interested in the public administration; Be engaged in an occupation not related to one's training and difficult to adjust and adapt; Capacity constraints leads to not get promotion; Personality; Interpersonal relationship problems, Negligent behavior and health status. Cui Peng(2011) argues that the promotion process is held in all kinds of "unspoken rule", which eventually causes some civil servants to resign. Zhang Fuqiang(2012) thinks that the reasons for CSRO include three dimensions of society, government and individual. Foreign scholars in recent years are also carried out empirical research on the cause of CSRO. Kim, Soonhee (2012) studies on how government IT employee turnover intention influences on human resource management, the results show that the promotion and development opportunities, training and development, management, communication system, pay satisfaction and family friendly policies are important variables influencing government IT employee turnover intentions. Huffman, Ann H. (2014) using samples of 5505 army officer from U.S., assess the spouse career support four years to some extent to influence employee job satisfaction and turnover behavior, the results show that the spouse career support can reduce the possibility of a departure. Watty - Benjamin, Wynant and Udechukwu lkwukananne(2014) research whether the human resource management practice is related to organizational citizenship behavior and turnover intention according to the case of public sector of Virgin island in the United States. The results of multiple regression analysis show that human resource management practices cannot predict organizational citizenship behavior and turnover intention.

\section{Analysis of the Reasons of CSRO in China}

Due to the particularity of Chinese social environment and institutional environment, the cause of CSRO has its own characteristics. Basedonthe research of scholars above, this paper will analyse the reasons for CSRO from 4 perspectives: the environment of political and economic, the functions of the resignation management system, incentive systemfailure and individual reason.

\subsection{The Environment of Political and Economic}

\subsubsection{The PoliciesofEconomic Construction and} Reform and Opening up ArethePull Factors of CSRO

China's economic development policy began in 1978. Socialist market economy system construction began in the 14th congress of CPC in 1992. Became a member of WTO in 2001.China economy has beensustained and developed rapidly, and becomes the world's second largest economic 
entity in 2011. Economic achievement is due to on one hand, the hardworking spirit of Chinese people and a large number of entrepreneurs. On the other hand,before 21 century, Chinese talent is not only small number, but reasonable structure. The talents in Party and government organs are relative surplus.Under the background of reform and opening-up, the dreams of the enterprise of industry serving country and creating wealth have been attracting a few civil servants of party and government organs to resign to do some business. Most of civil servants resigningare young and full of dreams, andknow economy and policy. Todaydozens ofwell-knownenterprises in
China,such as Vanke,DalianWanda,HC,Cathay Pacific,Taikanglife-insurance, etc., arefounded by the civil servants who resigned at that time. So it can be said that the human resources competition brought by the economic construction promotes the talents to optimal allocation, which is the pull factors of contemporary civil servants to resign. This phenomenonappears to bethe loss of government talents, actually many managementtalentschoose a more suitable job to do,the result is both enterprises get profit and government increases income.

Table 1 The number ofredundant civil servants were cut in the 4 reforms of 1982-1998 in Chinese State Council

\begin{tabular}{l|l|l|l|l}
\hline Year & $\begin{array}{l}\text { The number } \\
\text { before reform }\end{array}$ & $\begin{array}{l}\text { The number after } \\
\text { reform }\end{array}$ & The number is cut & Proportion \\
\hline 1982 & 51,000 & 38,300 & 12,700 & $15 \%$ \\
\hline 1988 & 52,800 & 44,800 & 8,000 & $15 \%$ \\
\hline 1993 & 50,000 & 30,000 & 20,000 & $40 \%$ \\
\hline 1998 & 32,000 & 16,000 & 16,000 & $50 \%$ \\
\hline
\end{tabular}

3.1.2. Institutional Reform and Cut Redundant

\section{Personnel Arethe PushFactors of CSRO}

Since 1982,China has experienced 6 majorinstitutional reforms.Especially the 4reforms before 1998,each must cuta large number ofredundant workers(Table 1).Every time thousands of civil servants of the state council is cut nearly, the number include governments at all levels is hundreds of thousands.Some of them retired, or went to the state-owned enterprises and public institutions to work, or studied in university at home and abroad, and some of them resigned of 
course. It is concluded that when somecivil servants still hesitated withthe temptation of the reform tide, the institutional reform gave them a wake-up-kick to help them to resign.

\subsubsection{The Establishment of Diversified Values}

The value orientation of Chinese tradition is "A good scholar will make an official", which still have a strong impact. However, since China's reform and opening up,people's professional values has been changing in quietly with the influence of the classic sayings of "One may distinguish himself in any trade"“Whetherawhitecatorablackcat,agoodcatcatch esmice" "Place a stall, is better than a county magistrate, horn rang, don't do county magistrate"“Industrial patriotic". During the process of contacting with enterprises and research institutions, some stronger professional civil servants gradually realize their own interesting. Thereforethey choose to resign to do business, or go to universities or research institutions to work.

\subsection{Institutional Reasons for CSRO}

\subsubsection{The Resignation System Supplies the}

\section{Legitimacyto Resign}

The target of CSRO systemisto clear thecivil serviceexports, which givescivil service opportunity to adjust occupationcareer again.Before 1984, there is the absence ofresignation system, and almost no phenomenon of cadresresignation.The first generation of doing business in the 1980s is not general civil servants, and mostof them did not resigncompletely.In 1984, “Decision onCentral Committee of CCP, the State Council Forbid Cadres of Party and Government Organs to Do Business"stipulated that "in-service cadres of party and government organs, if one requests to resign from office to manage individual or collective company, should be agreed". From that time,CSRO finally have the legal basis but there is strict limit condition. Both Provisional Regulations on State Civil Servants in1993 and The Civil Servant Law of the People's Republic of China in 2005 make clear a regulation that "resignation is a right of civil servants", which is the legal protection of civil servants resign. At the same time in order to complete the task of institutional reform and develop economy, many local governments have introduced preferential measures to encourage civil servants to resign to do business. Therefore it is concluded that resignation system and encourage local regulationinducessome civil servants to resign.

\subsection{2 . The Social Security System Related to Resign}

Has BeenImproved

The professional attraction of Civil servants is stable, good welfare and pension. However, national health system, pension system and social welfare system have been perfecting gradually in China. As long as you make more money when 
youwork, you can buy all kinds of insurances for you and your family. After retirement, you can enjoy better welfare than a civil servant. The social welfare system eliminate the welfare gap between different career, and remove the trouble afterCSRO.

A high official(ting ji)named Xu Gang was opposed by his family for two questions when he was going to resign. Firstly, "after resigning, what is your retirement security in the future?"He told his family that hecouldbuymore insurance without retirement pay, and would receive RMB5,000 per month at the age of 60. Secondly, "there is no free medical care, how to do?"He said hecould deposit 1000,000 for medical care.(Yang Ming, Zhang Lu, 2010)More and more perfect social security system provides strong guarantee for the civil servants resignation.

\subsection{Incentive System Failure}

\subsubsection{The LowerSalary}

It is a consensus thatcivil servants' working environment is stable, and there are some recessive welfare. However, it is an indisputable fact that civil servants are dissatisfied with wages level, the time limit of increase the wages and the rationality of pay in China. Compared with the average salary of the whole society, the average salary for civil servants do not low. However,we cannot hard to find that civil servants are elites of university graduates and societythrough the civil service exam hot hundreds or thousands of people compete a position. With their education investment, ability is concerned, they should get more considerable income in other jobs. Thereforeone oftarget of civil servants, especially leading cadres to resign is to earn more income with their own ability, and to improve the living standards of their family. Especially most of leading cadres resigned to enterprise almost got a higher position and salary. Whilethe resignation of ordinary civil servants does not increase salary at once, but hope to improve income in future.

\subsubsection{The"Ceiling" ofPromotion}

According to the personnel department statistics, the leadership abovethe grade of county magistrate or department director(xian chu ji) is only $8 \%$ of the total number of civil servants. Most of civil servants are still section head(zhu ren ke yuan)when their retirement. The higher of leadership grades, the fewer jobs. Therefore leading cadres always meet the"ceiling" of promotion, to a certain leadership level, there is no space of promotion. Wu Minyi,a former vice mayor of Wenzhou talked about the resignation reason: "now that to be a leader, of course, one hopes to have a higher stage which is matched withone's own ability. However, the promotion opportunity is not decided by oneself. Knowing that, you are not stubbornly and will make your choice"(Zhang Jingping, 2004).One of resignation of reason can be 
summarized that the space of leadership promotion is limited, Changing another stage can play one's advantage.

\subsubsection{Unfair Treatment}

The forms of unfair treatment in China include injustice promotion,injustice pay, Leadership unfair, injustice dispose,sexual harassment, etc. C.E.Rusbult (1988) argued that the first reaction or action is to leave the organization and forget it after employees suffering from unfair treatment. Therefore unfair treatment is one of reasons to cause CSRO.

\subsection{Individual Reasons}

\subsubsection{Willing to Try Challenging Work or Do}

\section{What One Likes}

Research results show that to be engaged in the work one lovesorto do certain challenging work really can stimulate individual's working enthusiasm and working potential. Most of civil servants have the idea of resignation, but dare not resign because of being afraid of difficulty. However, a few with management potential and entrepreneurial spirit choose to resign and start again for their interesting. It is hard to understand some resignation behavior because of their better position and condition in government. Why to resign? The answer is to do what one wants to do. Jiang Chongzhou, a high grade leadership(ting ji), in an interview with the southern metropolis daily, concluded his resignation reason: "Anyway I am going to do what I want. Whether you are good at it or not, you should go to give it a try, do not leave regret"(Zhang Jingping, 2004). More than 30 years, many resigned civil servantshave been holding their ideal of doing business, although most of them did not make expected success, but they gain rich experience.

\subsubsection{Job Burnout}

"Job Burnout" is put forward earliest by Freudenberger in 1974. Maslach and Jackson (1975) put forward the concept of job burnout of multidimensional, namely emotion exhaustion, depersonalization, $\quad$ reduced personal accomplishment from the perspective of social psychology.The situation of the civil servant's job burnout: an investigation in September 2007 for civil servants from Wenzhou showed that " $50 \%$ of civil servants thinks mechanization of work, feel tired and stressed; and $40 \%$ has obvious job burnout, only $10 \%$ feels to own passion and specific goals". Another investigation in 2007 from Guangdong province showed that " $50.3 \%$ of young civil servants often feels pressure, $31.2 \%$ feels too tired, sometimes even $11.6 \%$ thinks of suicide".(Zhang peng, Sun Guoguang,2008) One of results of job burnout is to cause some civil servants to resign. For example, Xiao zhao, female, 31 years old, graduate student, worked in a 
government department for five years, then resign to go to an university as a civil servant training manager, and feel satisfied with work now. Her resignation reason is that the work of the government is not very busy, but she still feels tired and hopeless (Liu Yaochen, Wang Jian,2011).

\subsubsection{The Change of Family Relationships}

Such as one of a spouse working in different places resigns to solve livingapart in two places. Or divorce may leads to resign. In the interviews, a provincialcivil servicetold me that he rarely heard the phenomenon of CSRO. But in his impression, a female civil servant in his organization resigned because a traffic accident killed her boyfriend and she had no way to go out the sorrow environment. Finally she had to resign from the sad environment to start a new life. In the situation, the reason of resignation has no relation with work, only the change of family relationships.

\section{Conclusions}

The reasons of CSRO in this paper can be concluded 4 perspectives and 11 specific reasons(table 2) which will impact on the tendency of Chinese CSRO in future. Especially since the 18th congress of the Communist Party of China in 2012, the new central government continues to deepen market economy construction and promote the reform of the administrative system. And a series of rules and prohibits have been implemented to regulate public behavior of civil servants. In this context, the phenomenon of CSRO will increase. Therefore, on the basis of the above 4 perspectives 11 reasons, it is very necessary to strengthen research, and take some measures to govern the trend

of

CSRO.

Table 2 The Reason of CSRO in China

\begin{tabular}{l|l}
\hline Perspectives & The Specific Reasons \\
\hline The environment of & The policiesof economic construction and reform and opening up arethe pull \\
political and & factors of CSRO \\
\cline { 2 - 2 } economic & Institutional reform and cut redundant personnel arethe push factors of CSRO \\
\cline { 2 - 2 } & The establishment of diversifiedvalues \\
\hline \multirow{2}{*}{$\begin{array}{l}\text { Institutional reasons } \\
\text { for CSRO }\end{array}$} & The resignationsystem supplies the legitimacyto resign \\
\cline { 2 - 2 } Incentive & The social security system related to resign has been improved \\
\hline \multirow{2}{*}{ systemfailure } & The lower salary \\
\cline { 2 - 2 } & The"ceiling" of promotion \\
\cline { 2 - 2 } & Unfair treatment \\
\hline Individual Reasons & Willing to try challenging work or do what one likes \\
\cline { 2 - 2 } & Job Burnout \\
\cline { 2 - 2 } & The change of family relationships \\
\hline
\end{tabular}




\section{Acknowledgement}

This is paper is a phased research result ofYunnan University of Finance and Economics "Talent Introduction" Project: " Research on problems and countermeasures ofCSRO-According to the case ofYunnan province "; National Social Science Fund Young Project of China: "To Create the System of China's Advanced Professional Technical Civil Servants" (Project approval number: 13CZZ045).

\section{References}

(1) C.E.Rusbult, et.all. (1988I). Impact of ExchangeVarialbes on Exit, Voice, Loyalty and Neglect: An Integrative Model of Responses to Declining Job Satisfaction[J]. Academy of Management Journal, 31, 599-627.

(2) Cui. Peng. (2011). "Unspoken Rule" Breaking Social Justice, Powerless People Feel Anxiety[N]. People's Daily, Edition 18, August 11

(3) Freudenberger H.J. (1974) Staff Burnout. Journal of Social Issues, 1,159-165.

(4) Huang, Renzong. (2001). System Analysis of CSRO to Do Business[J]. Decisionmaking Consultation, 10,18-20.

(5) Huffman, Ann H. ; Casper, Wendy J.; Payne, Stephanie C. (2014). How Does Spouse Career Support Relate to Employee Turnover? Work Interfering with Family and Job Satisfaction as Mediators[J]. Journal of Organizational Behavior. (2):194-212.

(6) Kim, Soonhee. (2012). The Impact of Human Resource Management on State Government IT Employee Turnover Intentions[J]. Public Personnel Management. (2): 257-279.
(7) Li Xiaoyu, Gao Dongdong and Gao Feng. (2007). The Party and Government Cadres' Job Burnout, Turnover Intention, Selfefficacy, Job Performance Relationship[J]. China Journal of Health Psychology,(7): 659-661.

(8) Liu, Junsheng. (2009). China Personnel System Overview[M]. Beijing:Tsinghua University Press, p139

(9) Liu, Yaochen, Wang Jian. (2011). Public Officials Stress Management Strategy[M]. China Personnel Press, (9): 191-192.

(10)Li, Tianji. (March,2014). Beijing Loss of More Than 500 Judges during 5 Years, More Than Three of Judges Do Not Trial Case[N], Beijing: Youth Daily

(11) ]Maslach C, Jackson. (1981). The Measurement

(12) of Experienced Burnout[J]. Journal of Occupational Behavior,(2): 99-113.

(13) Pan Chenguang. (2005). Chinese Report Talent[M]. Beijing: Social Sciences Academic Press

(14) Song Bin, Bao Jing, Xie Xin. (2005). Human Resources Development in Government Department[M]. Beijing:Tsinghua University Press, 2, 169171.

(15) Shen, Nianzu. (2014). The Young Judges Tell Frankly That BiggerPressure Less Pay, to Resign to $\mathrm{Be}$ Lawyers[N]. Economic Observation Network, February

(16) The National People's Congress. (2005). The Civil Servant Law of the People's Republic of China 
(17) The CSRC Officials Resign, How to Fire Prevention and Extinguishing[N]. (2012, October). Southern: Weekend,

(18) Wu, Bo. (2005). Contemporary China Talent flow $[\mathrm{M}]$. Beijing: People's Publishing House, 150-311

(19) Wang, Chao. (2002, May). A Huge Loss of Tax Avoidance[N]. China: Youth Daily

(20) Wang, Shengjun. (2010, March). There Are Five Aspects of Problems and Difficulties in the

People'sCourt[EB/OL].Http://www.people.c om.cn, 10, 2013.

(21) Watty, Benjamin. (2004). Wynant; Udechukwu, lkwukananne. The Relationship Between HRM Practices and Turnover Intentions: A Study of Government and Employee Organizational Citizenship Behavior in the Virgin Islands[J]. Public Personnel Management, 1, 58-82.

(22) Xu, Songtao,Sun, Jianli. (2009). Thirty Years of Reform of Chinese Personnel System[M]. China Personnel Press, 35-37.

(23) Yearbook of People's Republic of China. (2004)

(24) Yang, Ming, Zhang, Lu. Xu Gang:After ResigningforEight Years, Talk about Business[N]. LookEast Weekly, 29, 51.

(25)Zhang, JingPing. (2004). Contingency: from Officials Resignation to Businessman in Politics[M].Hangzhou: Zhejiang People's Publishing House, 12-20.

(26) Zhang, Peng, Sun, Guoguang. (2008). Civil Servant's Job Burnout Causes and Intervention Countermeasures $[\mathrm{J}]$. Chinese Public Administration, 10,17.
(27) Zhang, Fujiang. (2012). Government Management Talent Flow Behavior and Reason Analysis Based on the Three Dimensions[J]. Value Engineering, 27, $285-2$ 